\title{
Insights into GABA Receptor Signalling in TM3 Leydig Cells
}

\author{
Richard F.G. Doepner ${ }^{a}$ Christof Geigerseder ${ }^{a}$ Monica B. Frungieri ${ }^{b}$ \\ Silvia I. Gonzalez-Calvar ${ }^{b}$ Ricardo S. Calandra ${ }^{b}$ Romi Raemsch ${ }^{a}$ Karl Föhr $^{c}$ \\ Lars Kunz $^{\mathrm{a}}$ Artur Mayerhofer ${ }^{\mathrm{a}}$ \\ ${ }^{a}$ Anatomisches Institut, Ludwig Maximilians University, Munich, Germany; ${ }^{b}$ Instituto de Biologia y Medicina \\ Experimental, Buenos Aires, Argentina; ${ }^{\mathrm{C}}$ Institute of Anaesthesiology, University of UIm, Ulm, Germany
}

\section{Key Words}

$\gamma$-Aminobutyric acid $\cdot \gamma$-Aminobutyric acid receptors $\cdot$

Testis · Leydig cells · Early growth response factor egr-1 - Mice

\begin{abstract}
$\gamma$-Aminobutyric acid (GABA) is an emerging signalling molecule in endocrine organs, since it is produced by endocrine cells and acts via $\mathrm{GABA}_{A}$ receptors in a paracrine/autocrine fashion. Testicular Leydig cells are producers and targets for GABA. These cells express $G_{A B A}$ receptor subunits and in the murine Leydig cell line TM3 pharmacological activation leads to increased proliferation. The signalling pathway of GABA in these cells is not known in this study. We therefore attempted to elucidate details of $\mathrm{GABA}_{A}$ signalling in TM3 and adult mouse Leydig cells using several experimental approaches. TM3 cells not only express $\mathrm{GABA}_{A}$ receptor subunits, but also bind the GABA agonist $\left[{ }^{3} \mathrm{H}\right]$ muscimol with a binding affinity in the range reported for other endocrine cells $\left(\mathrm{K}_{\mathrm{d}}=2.740 \pm 0.721 \mathrm{nM}\right)$. However, they exhibit a low $B_{\text {max }}$ value of $28.08 \mathrm{fmol} / \mathrm{mg}$ protein. Typical $\mathrm{GABA}_{A}$ receptor-associated events, including $\mathrm{Cl}^{-}$currents, changes in resting membrane potential, intracellular $\mathrm{Ca}^{2+}$ or cAMP, were not measurable with the methods employed in TM3 cells, or, as studied in part, in primary mouse Leydig cells. GABA or $\mathrm{GABA}_{A}$ agonist isoguvacine treat-
\end{abstract}

ment resulted in increased or decreased levels of several mRNAs, including transcription factors (c-fos, hsf-1, egr-1) and cell cycle-associated genes (Cdk2, cyclin D1). In an attempt to verify the cDNA array results and because egr-1 was recently implied in Leydig cell development, we further studied this factor. RT-PCR and Western blotting confirmed a time-dependent regulation of egr-1 in TM3. In the postnatal testis egr-1 was seen in cytoplasmic and nuclear locations of developing Leydig cells, which bear $\mathrm{GABA}_{A}$ receptors and correspond well to TM3 cells. Thus, GABA acts via an untypical novel signalling pathway in TM3 cells. Further details of this pathway remain to be elucidated.

Copyright $\odot 2005$ S. Karger AG, Basel

\section{Introduction}

The neurotransmitter $\gamma$-aminobutyric acid (GABA) exerts its actions via the ionotropic $\mathrm{GABA}_{\mathrm{A}}$ and $\mathrm{GABA}_{\mathrm{C}}$ receptors, as well as via the metabotropic $G_{A B A}$ receptor. The $\mathrm{GABA}_{\mathrm{A}}$ and $\mathrm{GABA}_{\mathrm{C}}$ receptors are pentameric $\mathrm{Cl}^{-}$channels, which are formed from different subunits $\left(\mathrm{GABA}_{\mathrm{A}}\right.$ receptor: $\alpha 1-6, \beta 1-4, \gamma 1-4, \delta, \varepsilon, \phi ; \mathrm{GABA}_{\mathrm{C}}$ receptor: $\rho$ 1-3). $\mathrm{GABA}_{\mathrm{B}}$ receptors are G-protein-coupled and mediate the GABA signal via several second messenger pathways [1]. Specific pharmacologically defined agonists and antagonists exist for each receptor type.

\section{KARGER}

Fax +41613061234 E-Mail karger@karger.ch www.karger.com (c) 2005 S. Karger AG, Basel 0028-3835/05/0816-0381\$22.00/0

Accessible online at: www.karger.com/nen
Artur Mayerhofer

Molecular Anatomy, Anatomisches Institut, Universität München

Biedersteiner Strasse 29, DE-80802 München (Germany)

Tel. +49894140 3150, Fax +4989397035

E-Mail Mayerhofer@lrz.uni-muenchen.de 
GABA and GABA receptors are not only found in the central nervous system, but also in peripheral endocrine organs, for example in growth hormone $(\mathrm{GH})$ cells of the anterior pituitary lobe [2-4], in pancreatic islets [5-7] and in the testis of human and rodents $[8,9]$. In these endocrine tissues, GABA, in general, is believed to regulate synthesis and release of hormones in an auto-/paracrine manner. However, we recently identified another GABAergic function in the testis. We found that GABA and a $\mathrm{GABA}_{\mathrm{A}}$ agonist stimulate proliferation of TM3 cells [10], a murine cell line of immature Leydig cells $[1,11]$. This action appeared to be mediated via a $\mathrm{GABA}_{\mathrm{A}}$ receptor, since the effect could be evoked by the $\mathrm{GABA}_{\mathrm{A}}$ receptor agonist isoguvacine and was blocked by bicuculline, $\mathrm{GABA}_{\mathrm{A}}$ receptor antagonist. Furthermore, several $\mathrm{GABA}_{\mathrm{A}}$ subunits were identified by RT-PCR in TM3 cells. Since in the postnatal testis Leydig cells also express $\mathrm{GABA}_{\mathrm{A}}$ receptor subunits and possess active GAD (glutamic acid decarboxylase) [8], we assume a functional role for locally produced GABA in developing Leydig cells.

Participation of GABA in migration, proliferation and differentiation of cells is known from the central nervous system, where GABA acting via $\mathrm{GABA}_{\mathrm{A}}$ receptors is involved in neurogenesis during embryonic development [12-17] and in progenitor cell proliferation in different regions of the developing brain [18-22]. Additionally, GABA is reported to be involved in neurite outgrowth [23] and migration $[24,25]$ of embryonic rat neurons. In all those cases, GABA acts as an auto-/paracrine factor as GABA synthesis and receptors are located in the same cell. The way of action of the $\mathrm{GABA}_{\mathrm{A}}$ receptor in immature neurons, contrary to mature neurons, is associated with depolarization of the cell membrane [14, 26, 27]. Despite the fact that there are many reports of non-synaptical GABA effects and actions, little is known about the subsequent intracellular pathways, but increased $\mathrm{Ca}^{2+}$ levels and altering cAMP levels are two documented possibilities [24, 28-32].

Based on our previous results implying $\mathrm{GABA}_{\mathrm{A}}$ mediated effects obtained in TM3 Leydig cells, we now aimed to identify details of the signalling cascade of GABA in TM3 cells focusing on cAMP, $\mathrm{Ca}^{2+}, \mathrm{Cl}^{-}$currents, changes in membrane potential and regulation of gene expression.

\section{Methods}

\section{Leydig Cells Purification}

Leydig cells were isolated from a pool of 16 testes obtained from 8 adult BALB/c mice (60-90 days of age; Technische Universität München). Leydig cells were isolated under sterile conditions using a discontinuous Percoll density gradient as previously described [33]. Cells that migrated to the $1.06-1.12 \mathrm{~g} / \mathrm{ml}$ density fraction were collected and suspended in Medium 199, yielding an 85-90\% enriched Leydig cell fraction. An aliquot was incubated for 5 min with $0.4 \%$ Trypan blue and used for cell counting and viability assay in a light microscope. Viability of Leydig cell preparations was 98-99\%.

\section{Cell Culture}

Isolated Leydig cells were cultivated in Medium 199 (SigmaAldrich, St. Louis, Mo., USA) at $37^{\circ} \mathrm{C}$ in an atmosphere containing 95\% air and 5\% carbon dioxide (vol/vol). TM3 cells were derived from immature mouse Leydig cells (d14) $[11,34]$ and were cultured in F12-DME medium (pH 7.2; Sigma, Deisenhofen, Germany) supplemented with 5\% horse serum (all from Biochrom AG, Berlin, Germany and PAA GmbH, Cölbe, Germany) and 2.5\% fetal calf serum FCS Gold (PAA). The cells were kept at $37^{\circ} \mathrm{C}$ in a humidified atmosphere containing air and carbon dioxide (95\%/5\% vol/ vol). In order to study egr- 1 expression, the cell cycles of TM3 cells were synchronized by culturing cells for $3 \mathrm{~h}$ in serum-reduced medium ( $1 \%$ fetal calf serum, $2.5 \%$ horse serum). TM3 cells were incubated subsequently in the same serum-reduced medium with $10 \mu M$ GABA, $10 \mu M$ GABA $_{\mathrm{A}}$ agonist isoguvacine and $10 \mu M$ $\mathrm{GABA}_{\mathrm{B}}$ agonist baclofen (Biotrend $\mathrm{GmbH}$, Cologne, Germany) for various time points $(5,10,15,30,60$ or $90 \mathrm{~min})$.

\section{Binding Assay}

For binding assays, TM3 cells were plated in 24-well plates for $24 \mathrm{~h}$. Each well contained approximately $5 \times 10^{5}$ cells in $250 \mu \mathrm{l}$ of serum-reduced medium (F12-DME, 2.5\% horse serum, 1.25\% fetal calf serum). The following day, cells (approx. 60-70 $\mu \mathrm{g}$ protein) were washed 3 times with F12-DME medium without serum and suspended in Tris-citrate buffer $(50 \mathrm{mM}, \mathrm{pH} 7.1$, final volume $250 \mu \mathrm{l})$. Saturation binding studies were performed with six concentrations of $\left[{ }^{3} \mathrm{H}\right]$ muscimol $(0.75-30 \mathrm{nM})$. Non-specific binding was determined in the presence of $100 \mu M$ unlabelled GABA. The mixture was incubated at $37^{\circ} \mathrm{C}$ under a humid atmosphere of $5 \%$ $\mathrm{CO}_{2}$ for $30 \mathrm{~min}$. Incubation was stopped by washing cells with F12DME medium without serum. Finally, cells were transferred into $1.6 \mathrm{ml}$ liquid scintillation cocktail (Optiphase Hisafe 2, Wallac Scintillation Products, Wallac Oy, Turku, Finland) for radioactivity counting. All individual assays were carried out in replicates of four. Scatchard plots were drawn by using the computer program PRISM (GraphPad, San Diego, Calif., USA). Dissociation constant $\left(\mathrm{K}_{\mathrm{d}}\right)$ was expressed in $\mathrm{n} M$. Maximal binding $\left(\mathrm{B}_{\max }\right)$ was expressed in $\mathrm{fmol} / 10^{6}$ cells and $\mathrm{fmol} / \mathrm{mg}$ protein. Protein concentration was measured using bovine serum albumin as standard.

\section{Immunohistochemistry}

For immunohistochemistry we employed a rabbit polyclonal antiserum against egr-1 (diluted 1:500; Santa Cruz Biotechnology, Inc., Santa Cruz, USA). Testicular distribution of egr-1 was examined in sections $(5 \mu \mathrm{m})$ of paraffin-embedded testes of $\mathrm{d} 5 / 6$ rodents. These tissue blocks have already been used in previous studies [35]. An avidin-biotin-peroxidase immunohistochemical method was employed as described previously [36]. A biotin-coupled polyclonal goat anti-rabbit antiserum (diluted 1:500; Jackson, Inc., West Grove, Pa., USA) served as secondary antiserum. Diaminobenzidine was used as a chromogen. Sections incubated with buffer alone, buffer containing rabbit non-immune serum and buffer containing egr- 1 antiserum, which was preadsorbed with egr-1 blocking 
peptide (both from Santa Cruz Biotechnology, Inc.), respectively, were used as controls. The sections were examined with an Axiovert photomicroscope (Zeiss, Oberkochen, Germany).

\section{Western Blotting}

For Western blot analyses we employed rabbit polyclonal antiserum against egr-1 (Santa Cruz Biotechnology, Inc.), and mouse monoclonal antiserum against $\beta$-actin (Sigma). Western blot analyses were performed with minor modifications as described previously [37]. In brief, TM3 cells were lyzed and homogenized by sonication in $62.5 \mathrm{mM}$ Tris- $\mathrm{HCl}$ buffer ( $\mathrm{pH}$ 6.8) containing $10 \%$ sucrose and $2 \%$ SDS, mercaptoethanol was added (10\%), and the samples were heated $\left(95^{\circ} \mathrm{C}\right.$ for $\left.5 \mathrm{~min}\right)$. Protein content was recorded using a Folin phenol quantitation method (DC protein assay, BioRad GmbH, München, Germany) [38]. Then, $15 \mu$ g protein per lane were loaded on Tricine-SDS-polyacrylamide gels $(12.5 \%)$, electrophoretically separated, and blotted onto nitrocellulose. Samples were probed with antiserum directed specifically against egr-1, and $\beta$-actin (incubation overnight at $4^{\circ} \mathrm{C}$, dilution 1:500). Immunoreactivity was detected using peroxidase-labelled goat anti-rabbit antiserum (diluted: 1:5,000; Jackson, Inc.) or peroxidase-coupled goat anti-mouse antiserum (diluted: 1:5,000; Jackson, Inc.) and an enhanced chemiluminescence detection kit (AmershamBuchler, Braunschweig, Germany).

\section{$R N A$ Preparation and Semiquantitative RT-PCR}

Isolation of RNA from TM3 cells, as well as RT and PCR for egr-1 and cyclophilin A were performed as described [39]. Conditions of PCR amplification consisted of 35 cycles $\left(94^{\circ} \mathrm{C}\right.$ for $30 \mathrm{~s}$, $55^{\circ} \mathrm{C}$ for $30 \mathrm{~s}, 72^{\circ} \mathrm{C}$ for $60 \mathrm{~s}$, followed by final extension for $5 \mathrm{~min}$ at $72^{\circ} \mathrm{C}$ ). Oligonucleotide primers (egr-1: sense $5^{\prime}$-acaagaaagcagacaaaagtg- $3^{\prime}$, antisense 5'-gtcgctgtcatgtctgaaag-3'; cyclophilin A: sense $5^{\prime}$-tggcaagtccatctacgg- $3^{\prime}$, antisense $5^{\prime}$-gagctacagaaggaatgg- $3^{\prime}$ ) were synthesized according to published sequences. Verification of cDNAs was achieved by direct sequencing [40].

\section{cDNA Array Studies}

We used the mouse pathfinder 1 GEArray and the GEArray Q series mouse signal transduction pathwayfinder gene arrays (Superarray, Inc., Bethesda, Md., USA) to analyze the GABA-regulated genes in TM3 cells, comparing unstimulated versus GABA $(10 \mu M)$ or isoguvacine $(10 \mu M)$ treated cells after 60,90 or $120 \mathrm{~min}$. The arrays were performed following the instructions provided by the manufacturer and as described before [41]. In brief, array membranes were hybridized with biotin-labelled cDNA and after binding of alkaline phosphatase-conjugated streptavidin and addition of CDPStar solution the chemiluminescence signals of the spotted genes were detected by exposing the membranes to x-ray films (Hyperfilm, Amersham Pharmacia Biotech, Little Chalfont, Bucks., UK). Digitized images were evaluated as illustrated previously [41].

\section{Electrophysiological Recordings}

Cells were perfused with an 'extracellular' medium containing $140 \mathrm{~m} M \mathrm{NaCl}, 2.7 \mathrm{~m} M \mathrm{KCl}, 1 \mathrm{~m} M \mathrm{MgCl}_{2}, 1.5 \mathrm{~m} M \mathrm{CaCl}_{2}, 6 \mathrm{~m} M$ glucose and $12 \mathrm{~m} M$ Hepes, $\mathrm{pH}$ was adjusted to 7.3. The medium was exchanged continuously at about $4.5 \mathrm{ml} / \mathrm{min}$. The membrane conductance of the cells was determined at room temperature (23$25^{\circ} \mathrm{C}$ ) by using the whole-cell recording mode of the patch-clamp technique. The equipment consisted of an EPC-9 patch-clamp amplifier and TIDA software as provided by HEKA (Lambrecht, Ger- many). The patch pipettes were drawn from borosilicate glass with a pipette resistance of 3-6 $\mathrm{M} \Omega$ and filled with an 'intracellular' medium containing $140 \mathrm{~m} M \mathrm{KCl}, 2 \mathrm{mM} \mathrm{Na} \mathrm{ATP}_{2} 2 \mathrm{~m} M \mathrm{MgCl}_{2}$, $2 \mathrm{~m} M$ EGTA, $10 \mathrm{~m} M$ Hepes, and $\mathrm{pH}$ was adjusted to 7.2. In order to improve sealing, the pipette was briefly dipped into $2 \%$ dimethyldichlorosilane, dissolved in methylene chloride. Membrane currents were recorded with membrane potential clamped to $-80 \mathrm{mV}$.

\section{Fluorescence Measurements}

(a) $\mathrm{Ca}^{2+}$ measurements were performed as described [42]. Briefly, the cells were loaded with Fura-2/AM (2.5 $\mu M$, dissolved in DMSO) for $30 \mathrm{~min}$ at $37^{\circ} \mathrm{C}$ in a standard external solution, consisting of $140 \mathrm{~m} M \mathrm{NaCl}, 2.7 \mathrm{~m} M \mathrm{KCl}, 1.5 \mathrm{~m} M \mathrm{CaCl}_{2}, 1 \mathrm{~m} M \mathrm{MgCl}_{2}$, $6 \mathrm{~m} M$ glucose, $12 \mathrm{~m} M$ HEPES, $\mathrm{pH}$ adjusted to 7.3. Before measurements, cells were extensively rinsed with the dye-free solution. Fluorescence measurements were performed with the Zeiss Fast Fluorescence Photometry System (MPM-FFP, Zeiss) which is based on an inverted microscope (Axiovert 35), equipped for epifluorescence. The excitation wavelength was switched, at $400 \mathrm{~Hz}$, between 340 and $380 \mathrm{~nm}$ using appropriate interference filters (bandwidth $10 \mathrm{~nm}$ ) mounted alternatingly in a filter wheel. This system allows one to monitor the emitted light $(505-530 \mathrm{~nm})$ with a time resolution of $5 \mathrm{~ms}$ for one pair of excitation wavelengths. The recorded data were averaged to achieve a final time resolution of $80 \mathrm{~ms} . \mathrm{Ca}^{2+}$ levels are given in the figures as fluorescence ratios obtained from alternating excitation at 340 and $380 \mathrm{~nm}$.

(b) The resting membrane potential $\left(\mathrm{V}_{\mathrm{R}}\right)$ was monitored using the fluorescent potential probe $\mathrm{DiBAC}_{4}(3)$ (Molecular Probes, Eugene, Oreg., USA) which distributes over the plasma membrane dependent on $\mathrm{V}_{\mathrm{R}}$. DiBAC $\mathrm{Di}_{4}(3)$ is one of the most sensitive potential probes available ( $1 \%$ fluorescence change per $\mathrm{mV}$ ), but reacts rather slow (about 30-60 s). Real-time intracellular $\mathrm{DiBAC}_{4}(3)$ fluorescence was imaged in a recording chamber mounted on a TCS SP2 confocal microscope (Leica Microsystems, Heidelberg, Germany). The potential probe was excited at $488 \mathrm{~nm}$, fluorescence was detected in the range from 500 to $540 \mathrm{~nm}$ and the intracellular signal intensity was quantified. Cells were preincubated with $1 \mu M$ Di$\mathrm{BAC}_{4}(3)$ containing extracellular solution $(140 \mathrm{mM} \mathrm{NaCl}, 3 \mathrm{mM}$ $\mathrm{KCl}, 1 \mathrm{~m} M \mathrm{CaCl}_{2}, 10 \mathrm{~m} M$ Hepes, $10 \mathrm{~m} M$ glucose, $\mathrm{pH}$ 7.4) for 10 min. Then, GABA $(100 \mu M)$ dissolved in the $\operatorname{DiBAC}_{4}(3)$ solution was applied for up to $10 \mathrm{~min}$ by a fine steel needle placed in close proximity to the cells.

Drug Application for Electrophysiological Recordings and $\mathrm{Ca}^{2+}$ Measurements

Agents were applied to the cells using the L/M-SPS- 8 superfusion system (List, Darmstadt, Germany). To restrict the presence of the agent to a small volume within the Petri dish, a combination of two perfusion systems was installed, i.e. (i) a global bath perfusion with the inflow set at $4.5 \mathrm{ml} / \mathrm{min}$ and an outflow which removed any excess fluid, and (ii) a local bath perfusion that generated a continuous fluid stream containing the agent in the desired concentration. The local inlet (tip of an eight-barrelled pipette) was positioned at a distance of 50-100 $\mu \mathrm{m}$ upstream and the local outlet at about $300 \mu \mathrm{m}$ downstream of the measuring field. Drugs were administered by a combination of gravity and an additional pressure control system which resulted in a flow rate of about $1 \mathrm{ml} / \mathrm{min}$. The selection among the 8 syringes connected to the eight-barrelled pipette was controlled with magnetic valves. 


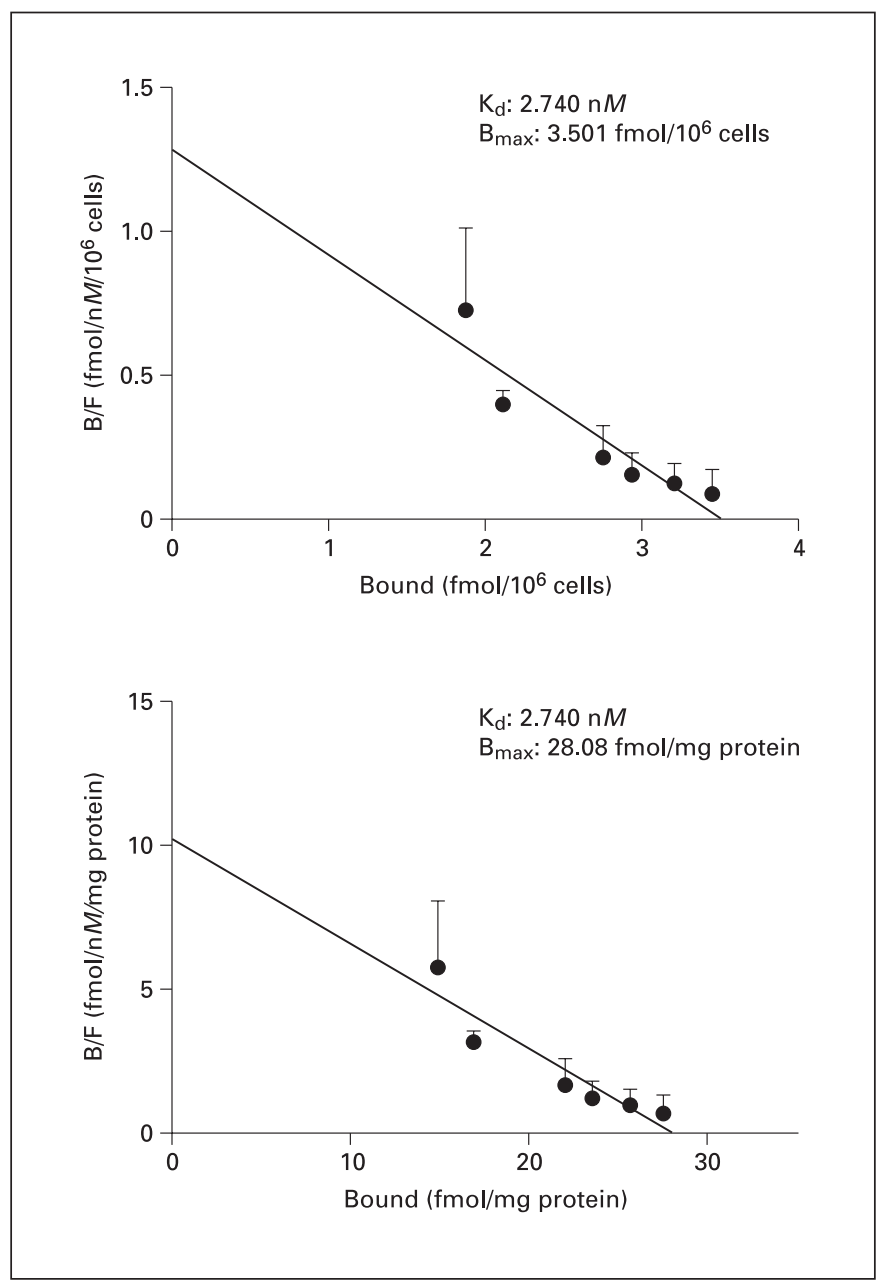

Fig. 1. Scatchard plot of $\left[{ }^{3} \mathrm{H}\right]$ muscimol binding to TM3 cells. Results of muscimol binding to TM3 cells (one of two experiments yielding almost identical results) is shown and results are expressed per cell number and protein content.

\section{cAMP Assay}

Measurements of cAMP levels were performed using TM3 cells either untreated or treated with GABA $(10 \mu M)$ employing a commercially available kit (Cayman Chemical, Ann Arbor, Mich., USA). After different incubation times, samples (supernatants and cell pellets) were frozen and stored at $-80{ }^{\circ} \mathrm{C}$ until analysis. The logarithmic standard curve was linear between 2.3 and $300 \mathrm{pmol} / \mathrm{ml}$.

\section{Results}

\section{Muscimol Binding Assay}

Scatchard analysis of $\left[{ }^{3} \mathrm{H}\right]$ muscimol binding to TM3 cells yielded a linear plot with a dissociation constant $\left(\mathrm{K}_{\mathrm{d}}\right)$ of $2.740 \pm 0.721 \mathrm{n} M$ and maximal binding $\left(\mathrm{B}_{\max }\right)$ of
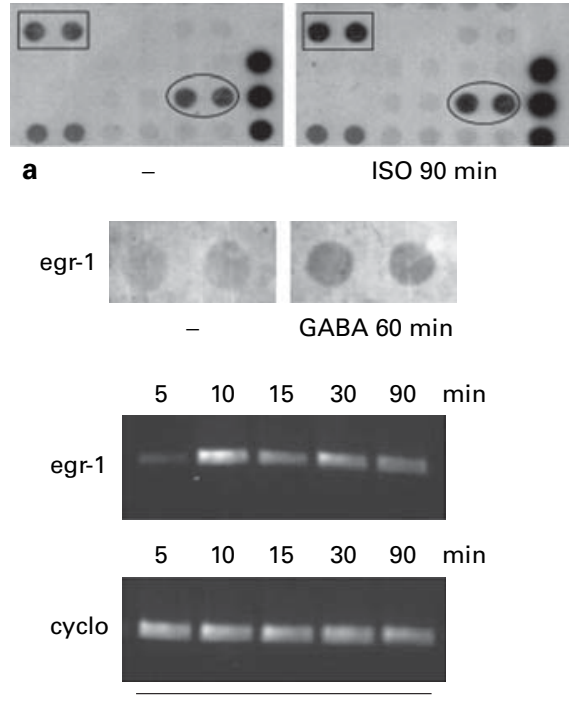

b

GABA

Fig. 2. Results from cDNA array studies and RT-PCR. a Example result from cDNA array studies showing that c-fos (boxed) and heat shock factor (hsf-1; circled) mRNA levels are increased 2- to 3-fold after $90 \mathrm{~min}$ of isoguvacine (ISO) treatment (10 $\mu \mathrm{M}$; duplicate blots). Compare with table 1 , in which results after $120 \mathrm{~min}$ are summarized and imply dynamic regulation of e.g. hsf-1. b Upper panel: Result from cDNA array study showing that egr-1 mRNA levels are increased after 60 min of GABA $(10 \mu M)$ treatment (duplicate blots). Lower panel: Semiquantitative RT-PCR showing egr-1 mRNA expression levels in TM3 cells from 5 to 90 min after $10 \mu M$ GABA treatment ( 1 representative of 3 independent experiments). Cyclophilin A (cyclo) expression at the same time points as control of potential loading differences.

$3.501 \pm 0.595 \mathrm{fmol} / 10^{6}$ cells or $28.080 \pm 4.774 \mathrm{fmol} / \mathrm{mg}$ protein (means \pm SEM). The results obtained are consistent with a single homogeneous population of binding sites (fig. 1).

$G A B A$ and the $G A B A_{A}$ Agonist Isoguvacine Increase the $m R N A$ and Protein Levels of egr-1 in TM3 Cells

cDNA array studies were performed with TM3 cells treated with GABA and with the $\mathrm{GABA}_{\mathrm{A}}$ receptor agonist isoguvacine for 60,90 and $120 \mathrm{~min}$. GABA $(10 \mu M)$ and isoguvacine $(10 \mu M)$ increased the levels of several mRNAs, including transcription factors, such as c-fos oncogene (c-fos, fig. 2a), heat shock factor 1 (hsf-1; fig. 2a) and early growth response factor 1 (egr-1; fig. 2b) and de- 
Table 1. Isoguvacine treatment $(10 \mu M)$ for 120 min reduced the transcript levels of several genes (data from cDNA array; optical densities were normalized to $\beta$-actin levels and expressed as ratio of untreated control and treated groups)

\begin{tabular}{ll}
\hline Name/Genebank Accession No. & Fold reduction \\
\hline Bone morphogenic protein 4 (NM007554) & 2.2 \\
Cyclin-dependent kinase 2L (AJ223732) & 2.5 \\
Cyclin D1 (M64403) & 1.8 \\
Engrailed homologue 1 (NM010133) & 7.0 \\
Glycogen synthase (U53218) & 2.8 \\
P53 (K01700) & 4.5 \\
Heat shock factor-1 (X61753) & 23 \\
Heat shock protein 90 (NM023633) & 3.3 \\
\hline
\end{tabular}

Compare figure 2 for up-regulated levels after $90 \mathrm{~min}$.

creased the mRNA levels of cyclin-dependent kinase 2L (cdk2; not shown), all at least 2-fold within 60-90 min. Levels of bone mophogenic protein 4 (BMP4), cyclin D1, $\mathrm{p} 53$, hsf-1, heat shock protein 90 and others were found to be decreased after 120 min of treatment with isoguvacine (table 1).

Because of its known involvement in the processes of mitosis and differentiation, we focused on the major transcription factor egr- 1 and attempted to verify theses results at mRNA and at the protein level. We confirmed by RT-PCR studies a GABA-induced up-regulation of egr-1 mRNA expression from 10 to 90 min (fig. 2b; $\mathrm{n}=3$ independent experiments) and a similar effect of isoguvacine ( $\mathrm{n}=2$ independent experiments; data not shown) in TM3 cells. These results are strongly supported at the protein level by further Western blot experiments, in which egr-1 protein levels were found to be increased after GABA and isoguvacine treatment in a time-dependent manner (fig. $3 ; n=5$ independent experiments).

\section{Immunolocalization of egr-1 in Testes}

In order to be able to judge whether egr- 1 is present in Leydig cells, immunostaining for egr-1 was performed in testicular sections of adult and immature (d5-6) rodent testes, namely mouse (not shown) and rat. Immunoreactivity of the transcription factor egr-1 was found in cytoplasmic as well as in nuclear location in proliferating interstitial Leydig cells at d5-6, but not in Leydig cells of adult testes. Immunostaining was specific since all controls performed including preadsorption of egr-1 antiserum were negative (fig. 4).

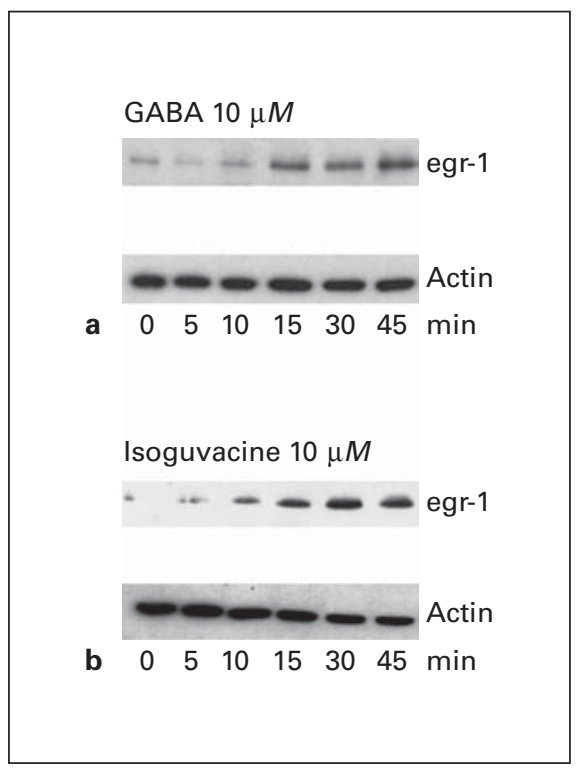

Fig. 3. Western blot results depicting expression pattern of egr-1 protein in TM3 cells after GABA/isoguvacine stimulation. Western blot experiments showing egr-1 protein levels after $10 \mu M$ GABA $(\mathbf{a}, \mathrm{n}=3)$ and $10 \mu M$ isoguvacine stimulation $(\mathbf{b}, \mathrm{n}=2)$. In order to take into account small loading differences, protein levels of $\beta$ actin were also analysed and are shown.

\section{Electrophysiological Studies and Analysis of Second Messenger Pathways in TM3 Cells and Isolated Leydig Cells during GABA Treatment}

Whole-cell patch-clamp experiments showed that acute treatment with GABA $(100 \mu M)$ did not induce any measurable $\mathrm{Cl}^{-}$currents in TM3 and adult Leydig cells (fig. $5 ; n=10$ cells each). In accordance with this result, no measurable change in resting membrane potential of TM3 cells was detected using the fluorescent potential probe $\mathrm{DiBAC}_{4}(3)$ (results not shown). Furthermore, fluorescence measurements indicated absence of measurable GABA $(100 \mu M)$-mediated alteration in intracellular $\mathrm{Ca}^{2+}$ levels in either cell type (data not shown). A cAMP assay performed in TM3 cells, likewise, showed no alteration of the cytoplasmic levels of this second messenger $30 \mathrm{~min}$ after GABA stimulation (values given as means \pm SD: $7.14 \pm 1.96 \mathrm{pmol} / \mathrm{ml} ; \mathrm{n}=6)$ in $\mathrm{TM} 3$ cells (untreated cells: $7.92 \pm 1.73 \mathrm{pmol} / \mathrm{ml} ; \mathrm{n}=6$ ) and therefore does not indicate involvement of this second messenger pathway. 
Fig. 4. Immunohistochemical detection of egr-1 in postnatal (day 6) and adult testes. a Immunoreactive egr- 1 is detected in nuclei of interstitial cells, some of which are very likely to represent cells of the adulttype lineage in the day 6 rat testis. Bar: $15 \mu \mathrm{m}$. b Groups of interstitial cells show immunoreactivity in the cytoplasm or in the nucleus in the day 6 rat testis. These groups most likely represent fetal-type Leydig cells. Bar: $15 \mu \mathrm{m}$. c Control staining of a day 6 testis, in which preadsorbed egr-1 antiserum was employed, resulting in complete absence of staining. Bar: $15 \mu \mathrm{m}$. d Staining with the egr- 1 antiserum in adult testis: Interstitial cells including Leydig cells are not stained and as expected [64] staining is restricted to the tubular compartment. Bar: $40 \mu \mathrm{m}$. e Control of an adult testis in which preadsorbed egr-1 antiserum was employed. Bar: $40 \mu \mathrm{m}$.

Fig. 5. Patch-clamp results of TM3 and adult Leydig cells treated with GABA. Patch-clamp results showing that GABA $(100 \mu M)$ does not evoke currents in TM3 (upper line) or in isolated Leydig cells (LC, lower line).
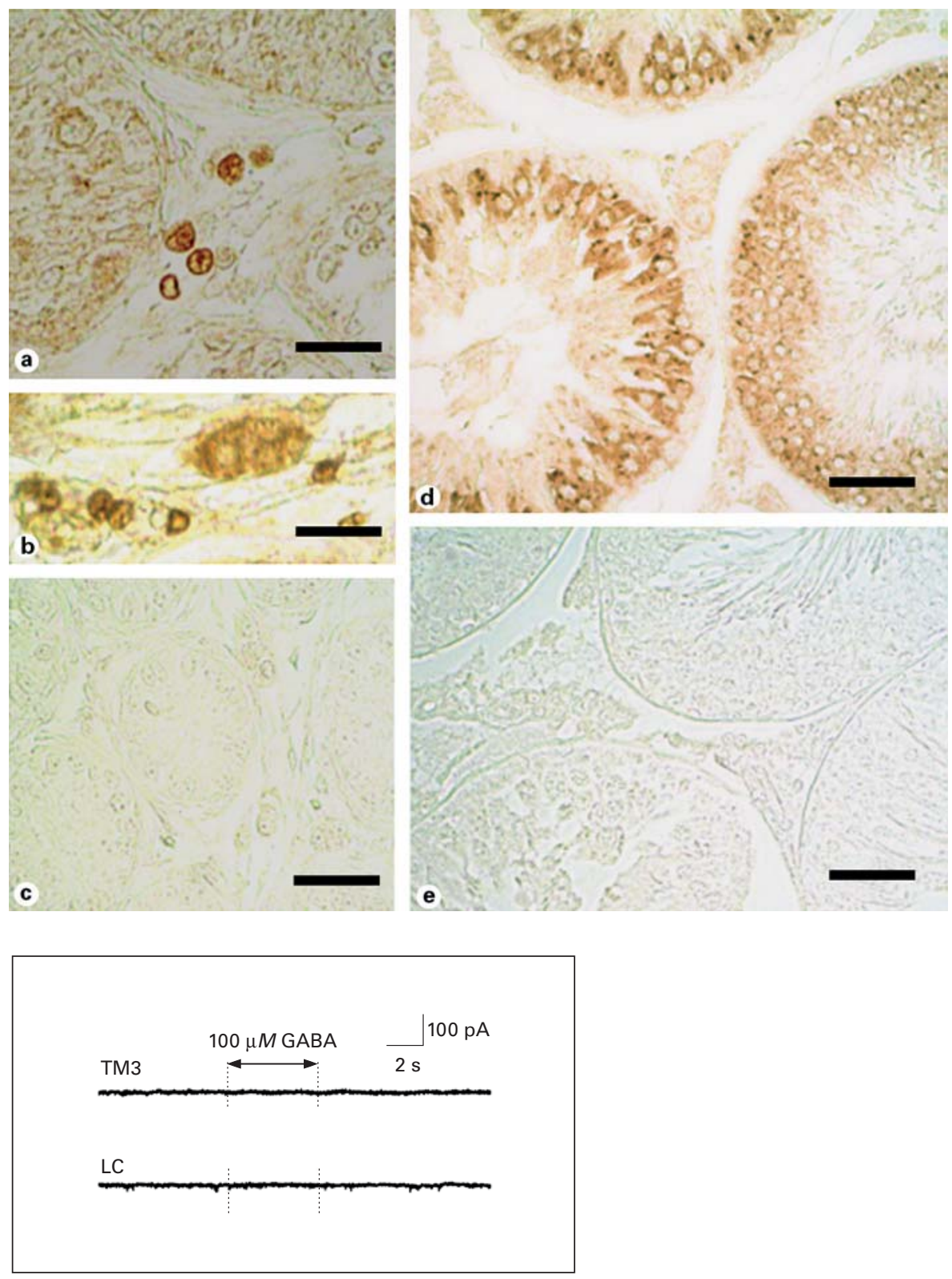

\section{Discussion}

Recently we provided evidence for testicular GABA production, testicular $\mathrm{GABA}_{\mathrm{A}}$ receptor subunit expression and GABA-induced Leydig cell proliferation. Therefore, we suggested that GABA is involved in development of Leydig cells in postnatal testis. Furthermore, based on actions of GABA agonists/antagonists on TM3 cells, which express $\mathrm{GABA}_{\mathrm{A}} \alpha, \beta$ and $\gamma$ subunits, we concluded that $\mathrm{GABA}_{\mathrm{A}}$ receptors are responsible for the initial signal transduction $[8,10]$.
In the present study we have attempted to analyze initial events in GABA action via the presumed $\mathrm{GABA}_{\mathrm{A}}$ receptor. Our results indicate that GABA binds to TM3 and may act via an unusual pathway, which does not include obvious changes in membrane potential, $\mathrm{Cl}^{-}$currents, changes of cAMP or $\mathrm{Ca}^{2+}$, but rather involves regulation of many genes, as was further verified for the master transcription factor egr-1.

TM3 Leydig cells are the main model system used for our studies, and as previously defined, they produce GABA, express the $\mathrm{GABA}_{\mathrm{A}}$ receptor subunits $\alpha 1, \alpha 2, \beta 1$, 
$\beta 3$ and $\gamma 1$ and respond to GABA and $\mathrm{GABA}_{\mathrm{A}}$ agonist treatment by increased proliferation [10]. TM3 cells thus resemble in particular the cells of the Leydig cell lineage found in the developing testis [10]. In some of our studies we also used isolated mouse Leydig cells, which, as our unpublished RT-PCR results showed, possess $\alpha 1, \alpha 2, \beta 3$ and $\gamma 3$ subunit mRNAs. These results are in line with a study examining $\mathrm{GABA}_{\mathrm{A}}$ subunit expression in the testis and other peripheral organs [43].

According to current knowledge the observed array of receptor subunits expressed by TM 3 should be sufficient to assemble in the cell membrane to form a functional $\mathrm{GABA}_{\mathrm{A}}$ channel [44-47]. $\mathrm{GABA}_{\mathrm{A}}$ receptors are pentameric channels and in the brain consist of mainly $\alpha 1, \beta 2$ and $\gamma 2$ subunits [48]. However, a multitude of different combinations exists due to the fact that multiple other subunits can assemble. Importantly it is thought that residues in the $\beta$ subunit may define high-affinity agonist binding [49], while the activation site for GABA is located at the $\alpha-\beta$ interface [50].

At least in TM3 cells, results from our studies with $\left[{ }^{3} \mathrm{H}\right]$ muscimol binding clearly indicated that GABA can efficiently bind to the membrane of these cells. The $\mathrm{K}_{\mathrm{d}}$ value obtained $(2.740 \pm 0.721 \mathrm{n} M)$ indicates affinities in the range as described for instance in brain, other endocrine cells or sperm [51-53]. Nevertheless, the $B_{\max }$ value $\left(3.501 \pm 0.595 \mathrm{fmol} / 10^{6}\right.$ cells; $28.080 \pm 4.774 \mathrm{fmol} / \mathrm{mg}$ protein), was 110-120 times lower than the one described in rat cerebellum [53] and bovine adrenal medulla [54], 60-70 times lower than those reported in rat brain [51], 15-25 times lower than those localized in human spermatozoa [52] and human ovary [55], and 4-5 times lower than those expressed in rat pituitary [53]. Thus, results obtained indicate that overall only few GABA-binding sites exist in TM3 cells, but they do not allow to judge whether all TM3 cells are equally endowed with binding sites or whether TM3 cells are heterogeneous in respect of their GABA receptor pattern. The detection of binding sites and $\mathrm{GABA}_{\mathrm{A}}$ receptor subunits alone does also not allow to conclude to typical, functional receptors. Although our previous immunohistochemical studies performed in developing and adult testes showed a $\mathrm{GABA}_{\mathrm{A}}$ $(\alpha 1)$ subunit protein in Leydig cells $[8,10]$, the full subunit composition in Leydig cells, like in any other peripheral endocrine organs, are to our knowledge not known.

The points mentioned are of importance in view of the observed 'electrophysiological silence' of TM3 and adult Leydig cells during GABA or isoguvacine treatment. These findings contrast markedly to reports on the brain, where all $\mathrm{GABA}_{\mathrm{A}}$ receptor-mediated effects described ap- pear to involve $\mathrm{Cl}^{-}$currents. One possible explanation could be related to an assembly pattern of $\mathrm{GABA}_{\mathrm{A}}$ receptor subunits different from the one of typical $\mathrm{GABA}_{\mathrm{A}}$ receptors in the brain, which may result in a receptor, but not in a functional, typical $\mathrm{Cl}^{-}$channel. Another possibility is that the methodologies employed in our studies were not sensitive enough to monitor small and fast GABA effects. In early neurogenesis, $\mathrm{GABA}_{\mathrm{A}}$ stimulation was shown to depolarize, rather than to hyperpolarize cells, and this led to elevated $\mathrm{Ca}^{2+}$ levels via opening of voltage-gated calcium channels [56-59]. Furthermore the second messenger cAMP has been implicated in neural and non-neural $\mathrm{GABA}_{\mathrm{A}}$ receptor signal transduction [2932]. Importantly, in some cases the depolarizing $\mathrm{GABA}_{\mathrm{A}}$ currents have been reported to be very small (1-4 pA) [23], a fact that may be related to only few receptors on the cell surface.

From our binding studies we can also conclude to low densities of binding sites corresponding to few $\mathrm{GABA}_{\mathrm{A}}$ receptor subunits on TM3. However, not only did we fail to detect $\mathrm{Cl}^{-}$currents using whole-cell patch-clamp techniques in at least 10 cells tested, but with an array of other methods performed in many cells, we also failed to measure changes in the cell membrane potential, intracellular $\mathrm{Ca}^{2+}$ or cAMP levels. Thus, our combined results indicate that the $\mathrm{GABA}_{\mathrm{A}}$ receptor of Leydig cells works through a mechanism different from the neuronal $\mathrm{GABA}_{\mathrm{A}}$ type.

That GABA and the $\mathrm{GABA}_{\mathrm{A}}$ agonist are active and selectively stimulate TM3 proliferation has been previously documented [10]. In the present study we obtained further proof of action that taken together indicate that GABA can affect a multitude of cellular functions. Thus in gene array studies we readily identified several genes that were altered. These include, for instance, up- and down-regulated genes, associated with cell differentiation (e.g. BMP4), cell cycle (cyclin D1, cdk2), other genes associated with several signalling pathways (p53, Engrailed-1, glycogen synthase) or transcription factors (including, c-fos, hsf-1) and the master transcription factor egr-1 [60-64].

We focused on egr-1 for several reasons. First, because it is not only known to be involved in cell proliferation, but also in a plethora of differentiation events. Second, because it can be induced by various stimuli and accordingly is ruled by several signalling pathways [61, 63]. Third, because an available specific antiserum allows to extend the study to the protein level and last, because this factor was recently identified to be present in immature rodent Leydig cells, but is absent in adult ones, indicated 
a role during development of Leydig cells [65]. Our combined results clearly confirm these data and furthermore, egr-1 is seen in the cytoplasm or nucleus of interstitial cells in the postnatal testis. Those cells, most of which can be readily identified as fetal Leydig cells or mesenchymal precursors of adult Leydig cells [for details, see 10], have been shown to bear $\mathrm{GABA}_{\mathrm{A}}$ receptors and to differentiate and to proliferate [10]. In particular the nuclear location of egr-1, i.e. a site where a transcription factor can be translocated and then presumably can act, provides at least circumstantial evidence that egr- 1 is involved in the developmental processes in the postnatal testis. In contrast, adult Leydig cells in adult testes completely lacked egr-1. The precise role of egr- 1 in differentiation and or proliferation remains to be studied, like the questions where in the signalling cascade egr-1 may act, and how it may interact with other signalling components. Pilot studies in our laboratory provide first hints that mitogenactivated kinase (erk1/2) could be involved.

In the developing brain, GABA has a role of a trophic molecule. In immature neurons prior to synapse formation, GABA is believed to rule cell migration, differentiation and proliferation during neuronal development via $\mathrm{GABA}_{\mathrm{A}}$-mediated events [reviewed in 14]. In developing testes, GABA in a similar fashion appears to be involved in development of Leydig cells [10]. Importantly, two independent reports provide further support for such a GABA action via egr-1 to occur in vivo. As mentioned, a recent study examining regulated genes during development from progenitor to adult stage of rat Leydig cells has identified egr-1 in progenitor cells, a result in accordance with our current study. However, egr-1 is subsequently down-regulated in adult Leydig cells [65], again a result in line with our present study. Furthermore, GABA is present in higher concentration in developing hamster testes, with a maximum at day 30 , than in adult testes [66]. Thus, GABA and egr-1 are both present in the developing testis and these independently derived results together with our present study imply that they are linked and may very well be involved in Leydig cell development.

In conclusion, our investigation, while failing to show expected typical $\mathrm{GABA}_{\mathrm{A}}$ receptor-associated signalling events known from neurons, reveals first details of a novel action of GABA in TM3 Leydig cells. Whether an unusual $\mathrm{GABA}_{\mathrm{A}}$ receptor and/or whether low densities of GABA receptors are responsible for the observed actions of GABA or its apparent absence in TM3 cells remains to be fully clarified.

\section{Acknowledgments}

We thank Barbara Zschiesche and Andreas Mauermayer for their expert technical assistance, Katia Gamel-Didelon, Martin Albrecht and Nicola Dimitrijevic for helpful discussions. This study was supported by DFG-Graduiertenkolleg 333 and a grant by DAAD and ANTORCHAS, fostering German-Argentinian scientific exchange.

The study presented is part of the work done in fulfillment of the requirements of the doctoral thesis of Richard Doepner at the Medical Faculty of the Ludwig Maximilians University Munich.

\section{References}

1 Bormann J: The 'ABC' of GABA receptors. Trends Pharmacol Sci 2000;21:16-19.

2 Gamel-Didelon K, Corsi C, Pepeu G, Jung H, Gratzl M, Mayerhofer A: An autocrine role for pituitary GABA: activation of GABA-B receptors and regulation of growth hormone levels. Neuroendocrinology 2002;76:170-177.

3 Gamel-Didelon K, Kunz L, Fohr KJ, Gratzl M, Mayerhofer A: Molecular and physiological evidence for functional $\gamma$-aminobutyric acid (GABA)-C receptors in growth hormone-secreting cells. J Biol Chem 2003;278:2019220195.

4 Mayerhofer A, Hohne-Zell B, Gamel-Didelon K, Jung H, Redecker P, Grube D, Urbanski HF, Gasnier B, Fritschy JM, Gratzl M: Gamma-aminobutyric acid: a para- and/or autocrine hormone in the pituitary. FASEB J 2001; 15:1089-1091.
5 Rorsman P, Berggren PO, Bokvist K, Ericson $\mathrm{H}$, Mohler H, Ostenson CG, Smith PA: Glucose-inhibition of glucagon secretion involves activation of $\mathrm{GABA}_{\mathrm{A}}$-receptor chloride channels. Nature 1989;341:233-236.

6 Gilon P, Bertrand G, Loubatieres-Mariani MM, Remacle C, Henquin JC: The influence of $\gamma$-aminobutyric acid on hormone release by the mouse and rat endocrine pancreas. Endocrinology 1991;129:2521-2529.

7 Satin LS, Kinard TA: Neurotransmitters and their receptors in the islets of Langerhans of the pancreas: what messages do acetylcholine, glutamate, and GABA transmit? Endocrine 1998; 8:213-223

8 Geigerseder C, Doepner R, Thalhammer A, Frungieri MB, Gamel-Didelon K, Calandra RS, Kohn FM, Mayerhofer A: Evidence for a GABAergic system in rodent and human testis: local GABA production and GABA receptors. Neuroendocrinology 2003;77:314-323.
9 Ritta MN, Calandra RS: Occurrence of GABA in rat testis and its effect on androgen production. Adv Biochem Psychopharmacol 1986;42: 291-297.

10 Geigerseder C, Doepner RF, Thalhammer A, Krieger A, Mayerhofer A: Stimulation of TM3 Leydig cell proliferation via $\mathrm{GABA}_{\mathrm{A}}$ receptors: a new role for testicular GABA. Reprod Biol Endocrinol 2004;2:13.

11 Mather JP: Establishment and characterization of two distinct mouse testicular epithelial cell lines. Biol Reprod 1980;23:243252

12 Ben Ari Y, Tseeb V, Raggozzino D, Khazipov R, Gaiarsa JL: Gamma-aminobutyric acid: a fast excitatory transmitter which may regulate the development of hippocampal neurones in early postnatal life. Prog Brain Res 1994;102: 261-273. 
13 Lauder JM, Liu J, Devaud L, Morrow AL: GABA as a trophic factor for developing monoamine neurons. Perspect Dev Neurobiol 1998; 5:247-259.

14 Owens DF, Kriegstein AR: Is there more to GABA than synaptic inhibition? Nat Rev Neurosci 2002;3:715-727.

15 Kriegstein AR, Owens DF: GABA may act as a self-limiting trophic factor at developing synapses. Sci STKE 2001;95:PE1.

16 Ben Yaakov G, Golan H: Cell proliferation in response to GABA in postnatal hippocampal slice culture. Int J Dev Neurosci 2003;21:153157.

17 Nguyen L, Rigo JM, Rocher V, Belachewl S, Malgrange B, Rogister B, Leprince P, Moonen G: Neurotransmitters as early signals for central nervous system development. Cell Tissue Res 2001;305:187-202.

18 Borodinsky LN, O’Leary D, Neale JH, Vicini S, Coso OA, Fiszman ML: GABA-induced neurite outgrowth of cerebellar granule cells is mediated by $\mathrm{GABA}_{\mathrm{A}}$ receptor activation, calcium influx and CaMKII and erk1/2 pathways. J Neurochem 2003;84:1411-1420.

19 Fiszman ML, Borodinsky LN, Neale JH: GABA induces proliferation of immature cerebellar granule cells grown in vitro. Brain Res Dev Brain Res 1999;115:1-8.

20 Haydar TF, Wang F, Schwartz ML, Rakic P: Differential modulation of proliferation in the neocortical ventricular and subventricular zones. J Neurosci 2000;20:5764-5774.

21 Stewart RR, Hoge GJ, Zigova T, Luskin MB: Neural progenitor cells of the neonatal rat anterior subventricular zone express functional $\mathrm{GABA}_{\mathrm{A}}$ receptors. J Neurobiol 2002;50:305322.

22 Kim MO, Li S, Park MS, Hornung JP: Early fetal expression of $\mathrm{GABA}_{\mathrm{B} 1}$ and $\mathrm{GABA}_{\mathrm{B} 2}$ receptor mRNAs on the development of the rat central nervous system. Brain Res Dev Brain Res 2003;143:47-55.

23 Maric D, Liu QY, Maric I, Chaudry S, Chang YH, Smith SV, Sieghart W, Fritschy JM, Barker JL: GABA expression dominates neuronal lineage progression in the embryonic rat neocortex and facilitates neurite outgrowth via $\mathrm{GABA}_{\mathrm{A}}$ autoreceptor/ $\mathrm{Cl}^{-}$channels. J Neurosci 2001;21:2343-2360.

24 Behar TN, Schaffner AE, Scott CA, O'Connell C, Barker JL: Differential response of cortical plate and ventricular zone cells to GABA as a migration stimulus. J Neurosci 1998; 18:63786387.

25 Behar TN, Schaffner AE, Scott CA, Greene CL, Barker JL: GABA receptor antagonists modulate postmitotic cell migration in slice cultures of embryonic rat cortex. Cereb Cortex 2000; 10:899-909.

26 Ben Ari Y: Excitatory actions of GABA during development: the nature of the nurture. Nat Rev Neurosci 2002;3:728-739.

27 LoTurco JJ, Owens DF, Heath MJ, Davis MB, Kriegstein AR: GABA and glutamate depolarize cortical progenitor cells and inhibit DNA synthesis. Neuron 1995;15:1287-1298.
28 Fukura H, Komiya Y, Igarashi M: Signaling pathway downstream of $\mathrm{GABA}_{\mathrm{A}}$ receptor in the growth cone. J Neurochem 1996;67:14261434.

29 Beltran-Parrazal L, Noris G, Clapp C, Martinez de la Escalera G: GABA inhibition of immortalized gonadotropin-releasing hormone neuronal excitability involves $\mathrm{GABA}_{\mathrm{A}}$ receptors negatively coupled to cyclic adenosine monophosphate formation. Endocrine 2001;14: 189-195.

30 Ritta MN, Bas DE, Tartaglione CM: In vitro effect of $\gamma$-aminobutyric acid on bovine spermatozoa capacitation. Mol Reprod Dev 2004; 67:478-486.

31 Yu TP, McKinney S, Lester HA, Davidson N: Gamma-aminobutyric acid type A receptors modulate cAMP-mediated long-term potentiation and long-term depression at monosynaptic CA3-CA1 synapses. Proc Natl Acad Sci USA 2001;98:5264-5269.

$32 \mathrm{Yu}$ TP, Lester HA, Davidson N: Requirement of a critical period of GABAergic receptor blockade for induction of a cAMP-mediated long-term depression at CA3-CA1 synapses. Synapse 2003;49:12-19.

33 Frungieri MB, Zitta K, Pignataro OP, Gonzalez-Calvar SI, Calandra RS: Interactions between testicular serotoninergic, catecholaminergic, and corticotropin-releasing hormone systems modulating cAMP and testosterone production in the golden hamster. Neuroendocrinology 2002;76:35-46.

34 Lee W, Mason AJ, Schwall R, Szonyi E, Mather JP: Secretion of activin by interstitial cells in the testis. Science 1989;243:396-398.

35 Mayerhofer A, Russell LD, Grothe C, Rudolf M, Gratzl M: Presence and localization of a 30-kDa basic fibroblast growth factor-like protein in rodent testes. Endocrinology 1991;129: 921-924

36 Mayerhofer A, Frungieri MB, Fritz S, Bulling A, Jessberger B, Vogt HJ: Evidence for catecholaminergic, neuron-like cells in the adult human testis: changes associated with testicular pathologies. J Androl 1999;20:341-347.

37 Hohne-Zell B, Gratzl M: Adrenal chromaffin cells contain functionally different SNAP-25 monomers and SNAP-25/syntaxin heterodimers. FEBS Lett 1996;394:109-116.

38 Peterson GL: Review of the Folin phenol protein quantitation method of Lowry, Rosebrough, Farr and Randall. Anal Biochem 1979; 100:201-220.

39 Fritz S, Wessler I, Breitling R, Rossmanith W, Ojeda SR, Dissen GA, Amsterdam A, Mayerhofer A: Expression of muscarinic receptor types in the primate ovary and evidence for non-neuronal acetylcholine synthesis. J Clin Endocrinol Metab 2001;86:349-354.

40 Fritz S, Fohr KJ, Boddien S, Berg U, Brucker C, Mayerhofer A: Functional and molecular characterization of a muscarinic receptor type and evidence for expression of choline acetyltransferase and vesicular acetylcholine transporter in human granulosa-luteal cells. J Clin Endocrinol Metab 1999;84:17441750.
41 Fritz S, Kunz L, Dimitrijevic N, Grunert R, Heiss C, Mayerhofer A: Muscarinic receptors in human luteinized granulosa cells: activation blocks gap junctions and induces the transcription factor early growth response factor- 1 . J Clin Endocrinol Metab 2002;87:1362-1367.

42 Fohr KJ, Mayerhofer A, Sterzik K, Rudolf M, Rosenbusch B, Gratzl M: Concerted action of human chorionic gonadotropin and norepinephrine on intracellular-free calcium in human granulosa-lutein cells: evidence for the presence of a functional $\alpha$-adrenergic receptor. J Clin Endocrinol Metab 1993;76:367-373.

43 Akinci MK, Schofield PR: Widespread expression of $\mathrm{GABA}_{\mathrm{A}}$ receptor subunits in peripheral tissues. Neurosci Res 1999;35:145-153.

44 Levitan ES, Schofield PR, Burt DR, Rhee LM, Wisden W, Kohler M, Fujita N, Rodriguez HF, Stephenson A, Darlison MG: Structural and functional basis for $\mathrm{GABA}_{\mathrm{A}}$ receptor heterogeneity. Nature 1988;335:76-79.

45 Malherbe P, Sigel E, Baur R, Persohn E, Richards JG, Mohler H: Functional characteristics and sites of gene expression of the $\alpha 1, \beta 1, \gamma 2-$ isoform of the rat $\mathrm{GABA}_{\mathrm{A}}$ receptor. J Neurosci 1990;10:2330-2337.

46 Sigel E, Baur R, Trube G, Mohler H, Malherbe $P$ : The effect of subunit composition of rat brain $\mathrm{GABA}_{\mathrm{A}}$ receptors on channel function. Neuron 1990;5:703-711.

47 Verdoorn TA, Draguhn A, Ymer S, Seeburg $\mathrm{PH}$, Sakmann B: Functional properties of recombinant rat $\mathrm{GABA}_{\mathrm{A}}$ receptors depend upon subunit composition. Neuron 1990;4:919928

48 McKernan RM, Whiting PJ: Which GABA receptor subtypes really occur in the brain? Trends Neurosci 1996;19:139-143.

49 Newell JG, Davies M, Bateson AN, Dunn SM: Tyrosine 62 of the $\gamma$-aminobutyric acid type A receptor $\beta 2$ subunit is an important determinant of high affinity agonist binding. J Biol Chem 2000;275:14198-14204.

50 Amin J, Weiss DS: GABA receptor needs two homologous domains of the $\beta$-subunit for activation by GABA but not by pentobarbital. Nature 1993;366:565-569.

51 Zhao XY, Wang Y, Li Y, Chen XQ, Yang HH, Yue JM, Hu GY: Songorine, a diterpenoid alkaloid of the genus Aconitum, is a novel $\mathrm{GABA}_{\mathrm{A}}$ receptor antagonist in rat brain. Neurosci Lett 2003;337:33-36.

52 Ritta MN, Calamera JC, Bas DE: Occurrence of GABA and GABA receptors in human spermatozoa. Mol Hum Reprod 1998;4:769-773.

53 Berman JA, Roberts JL, Pritchett DB: Molecular and pharmacological characterization of $\mathrm{GABA}_{\mathrm{A}}$ receptors in the rat pituitary. J Neurochem 1994;63:1948-1954.

54 Castro E, Oset-Gasque MJ, Canadas S, Gimenez G, Gonzalez MP: $\mathrm{GABA}_{\mathrm{A}}$ and $\mathrm{GABA}_{\mathrm{B}}$ sites in bovine adrenal medulla membranes. $\mathrm{J}$ Neurosci Res 1988;20:241-245.

55 Erdo SL, Laszlo A: High specific $\gamma$-aminobutyric acid binding to membranes of the human ovary. J Neurochem 1984;42:1464-1467. 
56 Owens DF, Boyce LH, Davis MB, Kriegstein AR: Excitatory GABA responses in embryonic and neonatal cortical slices demonstrated by gramicidin perforated-patch recordings and calcium imaging. J Neurosci 1996;16:64146423.

57 Yuste R, Katz LC: Control of postsynaptic $\mathrm{Ca}^{2+}$ influx in developing neocortex by excitatory and inhibitory neurotransmitters. Neuron 1991;6:333-344.

58 Lin MH, Takahashi MP, Takahashi Y, Tsumoto $\mathrm{T}$ : Intracellular calcium increase induced by GABA in visual cortex of fetal and neonatal rats and its disappearance with development. Neurosci Res 1994;20:85-94.
59 Leinekugel X, Tseeb V, Ben Ari Y, Bregestovski P: Synaptic $\mathrm{GABA}_{\mathrm{A}}$ activation induces $\mathrm{Ca}^{2+}$ rise in pyramidal cells and interneurons from rat neonatal hippocampal slices. J Physiol 1995;487:319-329.

60 Owens DF, Liu X, Kriegstein AR: Changing properties of $\mathrm{GABA}_{\mathrm{A}}$ receptor-mediated signaling during early neocortical development. J Neurophysiol 1999;82:570-583.

61 Beckmann AM, Wilce PA: Egr transcription factors in the nervous system. Neurochem Int 1997;31:477-510.

62 Khachigian LM, Collins T: Early growth response factor 1: A pleiotropic mediator of inducible gene expression. J Mol Med 1998;76: 613-616.

63 Thiel G, Cibelli G: Regulation of life and death by the zinc finger transcription factor Egr-1. J Cell Physiol 2002;193:287-292.
64 Topilko P, Schneider-Maunoury S, Levi G, Trembleau A, Gourdji D, Driancourt MA, Rao $\mathrm{CV}$, Charnay P: Multiple pituitary and ovarian defects in Krox-24 (NGFI-A, Egr-1)-targeted mice. Mol Endocrinol 1998;12:107-122.

65 Ge RS, Dong Q, Sottas C, Chen H, Zirkin B, Hardy M: Gene expression in rat Leydig cells during development from the progenitor to adult stage: a cluster analysis. Biol Reprod 2005;72:1405-1415.

66 Frungieri MB, Gonzales-Calvar SI, Chandrashekar V, Rao JN, Bartke A, Calandra RS: Testicular $\gamma$-aminobutyric acid and circulating androgens in Syrian and Djungarian hamsters during sexual development. Int J Androl 1996; 19:164-170. 